\title{
Return of Education for Women across Socio-Economic Status: Using Quantile Regression and Machado-Mata Decomposition Methods for Turkey*
}

\author{
Yağmur TOKATLIOĞLU1 $\odot$, Nükhet DOĞAN² $\odot$
}

\begin{abstract}
The purpose of this paper is to identify gender-based wage differentials through wage distribution. Although studies on gender-based wage differentials with the quantile regression method have been carried out before, this study contributes to the literature by way of gender-based wage differentials as determined by the Machado-Mata decomposition method. In this paper, TurkStat's 2017 Household Budget Survey data is examined. The total sample size is 10,073 respondents aged 15 years old or older. Our findings show that a significant portion of the wage differential is based on characteristic which should exist in the labor market and little is due to gender-based; but, it should not be ignored that due to gender-based wage differentials part. Nevertheless, it is found that gender-based wage differential is higher in low-income individuals than high-income individuals. This is important for women in low-income groups who are already disadvantaged. This paper reveals that the return on education and experience on wages is higher for women with low socio-economic status.
\end{abstract}

Keywords: Quantile Regression, Gender-Based Wage Differentials, Expanded Mincerian Wage Equations.

JEL Classification Codes: C21, J16, J24.

\section{Introduction}

The aim of this study is to determine gender-based wage differential through wage distribution and to evaluate how wage differential between men and women develops in Turkey. The model is estimated using the data set of the 2017 Household Budget Survey conducted by the Turkish Statistical Institute (TurkStat). By using the method described by Machado and Mata (2005), it is found that a large part of the wage differentials between men and women depends on covariate in the model, whereas very little depends on gender-based. As the wage distribution data is skewed in Turkey, it is appropriate to use quantile regression. Neo-classical economics defines discrimination as assessment of wages according to criteria that do not directly affect the productivity of the productive factors. Wage discriminations are the most common form among all discrimination types (McConnell, Brue and Macpherson, 2013). Discrimination in the labor market has severe implications for the economy, especially deterioration of distribution efficiency. For these reasons, it is essential to follow up and be able to measure wage differentials in the labor market, which will ensure economic efficiency.

In the case of wage differentials, based on social prejudices and that the employer's preferences are discriminatory, disadvantaged groups often receive lower wages because of their gender, sector, industry, races and religions. Women are included in the disadvantaged group. Studies by Oaxaca (1973), Dustmann and van Soest (1997), Dayoglu and Kasnakoglu (1997), Akcomak and Kasnakoglu (2003), Tansel (2003), Ozcan, Ucdogruk, and Ozcan (2003), Meurs and Ponthieux (2005), Kara (2006), Ilkkaracan and Selim (2007), Cudeville and Gurbuzer (2007), Thrane (2008), Garcia-Suaza et al., (2009), Guner (2009), Azam and Prakash (2010), Ismail (2011), Ersaslan (2012), Ismail and Jajri (2012), Celik and Selim (2014), Celik and Selim (2016), found

"This article is produced from a part of unpublished doctoral thesis approved by the author's Institute of Social Sciences, Gazi university. 'yagmur.tokatlioglu@hbv.edu.tr

${ }^{2}$ Prof. Dr., Ankara Hacı Bayram Veli Üniversitesi, iiBF, Ekonometri Bölümü Ankara, nukhet.dogan@hbv.edu.tr 
that female employees earn less than men. There is also discrimination based on public-private sector or industry differential or occupational (Dustmann and van Soest (1997), Tansel (2003), Ozcan, Ucdogruk, and Ozcan (2003), Tansel (2005), Hyder and Reilly (2005), Casero and Seshan (2006), Kara (2006), Lucifora and Meurs (2006), Gurler Kiren and Ucdoğruk (2007), Thrane (2008), Azam and Prakash (2010), Celik and Selim (2014), Tansel and Bircan Bodur (2012) and Mercan and Karakas (2015)), racial discrimination (Neal and Johnson (1996), Bertrand and Mullainathan (2004), Lang and Lehmann (2012), Borowczyk-Martins, Bradley, and Tarasonis (2017)) and religious discrimination (Blackaby et al., (1998), Brown (2000), Lindley (2002), Modood (2003), Brynin and Guveli (2012), Heath and Martin (2013)) in addition to gender discrimination.

Wage differentials studies have been comprehensively carried out in many countries by different methods, especially including the ordinary least squares (Casero and Seshan (2006), Garcia-Suaza et al., (2009), Andrada and Galassi (2009), Tansel and Bircan Bodur (2012), Celik and Selim (2014)), quantile regression (Budría and Pereira (2005), Tansel and Bircan Bodur (2012), Hyder and Reilly (2005), Lemieux (2006), Celik and Selim (2014), Celik and Selim (2016)), logit model (Tansel (2003) and Tansel (2005)), Oaxaca and Ransom (1994) decomposition methods (Silber and Weber (1999), Meurs and Ponthieux (2005), Fortin, (2008), Ismail (2011), Ismail and Jajri (2012)),Oaxaca-Blinder decomposition methods (Blinder (1973), Oaxaca (1973), Dayioglu and Kasnakoglu (1997), Ozcan, Ucdogruk, and Ozcan (2003), Kara (2006), Gurler and Ucdoğruk (2007), Ilkkaracan and Selim (2007), Cudeville and Gurbuzer (2007), Guner (2009), Azam and Prakash (2010), Akhmedjonov (2012), Ersaslan (2012), Mercan and Karakas (2015), Zhou, Zhao, Chou, and Leivang (2019)). Gardeazabal and Ugidos (2005) extended the scalar measurement of the Oaxaca method for quantile regression as the variance of men is higher in wage distribution as the dependent variable in comparison to women. This is precisely why Machado and Mata (2005) proposed an alternative method of decomposition that combines the quantile regression and bootstrap approaches to enable the counterfactual analysis in the Machado-Mata decomposition method used by Albrecht, Bjorklund and Vroman (2003), Fitzenberger and Kunze (2005), Heinze (2010), Arulampalam, Booth and Bryan (2007), de la Rica, Dolado and Llorens (2008), Albrecht, van Vuuren and Vroman (2009), Christofides, Polycarpou and Vrachimis (2013) and Aktas and Uysal (2016) for different countries.
In this study, expanded Mincerian wage equations were used to explain wages with the variables of education, experience and experience squared, full-time employee, head of household, married, family size, having children. Although there are numerous theoretical and empirical studies discussing the impact of human capital variables, particularly by Mincer (1974) and Card (1999), there are no universally accepted variables that should be included in researching the determinants of wages (Heinze, 2010: 13). The theory of human capital, which is developed to explain the role of labor force from production factors, is defined as the person's knowledge, skills and abilities that are innate (Schultz, 1961). Human capital allows usage of production factors more efficiently and effectively. In the literature, the most critical component of human capital is considered to be education.

This study contributes to the literature by the way of analyzing gender-based wage differentials with the Machado-Mata decomposition method. There are some methods for using wage differentials (as mentioned above), but some of these methods -ordinary least squares, logit model, Oaxaca-Blinder decomposition method- do not provide information about discrimination through the distribution, while some of these -ordinary least squares, logit model, quantile regression- do not decompose discrimination. Machado-Mata decomposition enables identification of how much of the actual wage differentials are based on gender by decomposing wage distribution. Aktas and Uysal (2016) used this decomposition for Turkey with firm-level data for 2006, but our data covers Turkey for 2017. The analysis shows that a significant portion of the wage gap is based on gender, and wage differentials are higher in the lower tail of the distribution.

The rest of the paper is organized as theoretical background, provision of data and method, empirical results, and finally, some concluding remarks.

\section{Theoretical Background}

Through the Industrial Revolution, the opportunity to make a more intense and mass production has been achieved. The production process, thus, entered a period where the capital and investment of capital gains importance while the labor force becomes less significant relatively. Technological innovations and their inclusion in the production process allowed to increase production until the middle of the 1900s, without paying much attention to the productivity of the labor force. However, since the transformation in 
technological developments and increase in the density of physical capital investments make it impossible to use unqualified labor force of the capital factor, the productivity increase of the labor force through human capital investments became a compulsory. From the beginning of the 1950s, as a result of studies of economists like Theodore Schultz (1961), Gary Becker (1962) and Jacob Mincer (1974), the fact that human capital investments are important in the production process has entered the literature. The labor force needs to become educated to use existing technologies, and even to detect defects arisen from the production process. The fact that, at the point of technological knowledge, unskilled labor does not efficiently increase production within the production process is now a widely accepted issue in the literature. Therefore, today, human capital investments have become very significant in the production process.

\section{Human Capital Investment}

In terms of economic development process, in the human capital theory developed to explain the role of the labor force, one of the production factors, human capital is defined as the whole of person's knowledge, abilities and innate talents (Schultz, 1961; Eyiusta and Ilhan 2015: 114). Human capital allows the production factors to be used more effectively and efficiently thanks to the education, knowledge and equipment of the labor force. According to the human capital theory, which was later comprehensively developed by supply-side economics, the skills and knowledge acquired by people through their education and work experience increase their marginal productivity, which leads them to get higher wages in the labor market (Becker, 1974). Human Capital Theory, developed by Becker (1974) and regarded as one of the classic approaches explaining the role of education in the economy, has three basic components of human capital investment: innate abilities, information acquired by schooling, and learning on-the-job. Therefore, wage differentials in the market can be explained using the human capital theory in this respect.

In the economic literature, it is stated that human capital investments have four different effects on the productivity of the labor force. The first of these effects is the individual efficiency-promoting effect of the labor force, which is also called the "laborer" effect. In the "allocation" effect, which is the second effect, compared to a less-educated labor force, a higher-educated labor force increases the productivity of other production factors faster. The third effect, the "spillover" effect, em- phasizes that a better-educated labor force can adapt to technological innovation more and demonstrate new production techniques more quickly. The final effect of human capital on labor productivity is the "research" effect. Accordingly, the increase in the higher-educated labor force in the production process will also encourage research and development activities (Cörvers, 1997: 976, 977). All these effects are factors that increase factor productivity.

When we look at the evolutionary development stages of human capital, on the other hand, it is seen that it has a branch that establishes a relationship between human capital and wage and works in this direction. In the approach shaped by the studies of economists such as Becker (1974), Mincer (1974), and Schultz (1961), as one's human capital investments increase, especially as the time of labor force spent in education increases, both individual productivity and productivity of other production factors increase. The fact that the labor force is equipped with a higher-education, therefore, indicates a higher-efficiency and higher real wages.

However, this direct-relation between education and wage in human capital theory is not expressed this much in all economic schools. Moreover, in some economic approaches, there is no direct relationship between human capital and education and wages. Education is the most important phenomenon that undermines the assumption that the labor force is homogeneous in fact. Different levels of education also have the feature of eliminating the effects of abilities or inabilities brought about by the labor force either innate or acquired in the first period of life. Education, therefore, has different effects on the labor market and each economic school addresses only some of these effects.

To summarize the development of the notion of human capital, each of them was derived from the search for solutions to the problems that their era tried to solve. Schultz (1961) made tangible connections between education and the concept of capital, he underlined the processes of learning on-the-job, and thus, he has changed the approaches of the Classical and Neoclassical economics related to the productivity of the labor force. Denison (1962) made the relation between human capital and education and wage differentials testable. Becker (1974) emphasized that the reasons for the income and wage differentials in the market were affiliated with the different education people have and human capital investments; Jorgenson and Griliches (1972), on the other hand, made the 
first study showing that there is a positive relationship between human capital and economic growth. While Mincer (1974) revealed the relationship between wage, education, and experience, while Lucas (1989) cited human capital investments as the reason for differences in economic growth rates between countries. Mankiw, Romer, and Weil (1992), on the other hand, explained the differentiation of countries' development with human capital investments and applied the notion of human capital to convergence theories. Jones (1996) and Barro (2001) emphasized that it is the human capital that provides the relationship between technology transfer and accumulation of physical capital.

One of the most important questions about education is the reason for the higher wage is due to the employee is better educated or has more skills. In addition, direct and alternative costs of education are still ignored in the literature (Blundell et.al, 1999: 3). The individual's decision to receive education depends on the efficiency of this education; in other words, its reflection on future earnings. Individuals need to earn higher salaries, including the costs of education, so that individuals can decide to receive education (Maazouz, 2013: 525).

\section{Wage Discriminations}

Neoclassical economics envisages the employment and pricing of production factors according to their marginal physical efficiency to ensure distribution efficiency in production. Therefore, neoclassical economics defines the assessment of wages according to criteria that do not directly affect the productivity of production factors as discrimination. In this context, neoclassical economics considers discriminations experienced in the labor market under four titles. Wage discrimination, the first discrimination in the labor market, is the pricing of the labor force according to features such as male-female, white-black, Muslim-Christian, Employment discrimination is the discrimination made by the employer in employment preferences according to personal characteristics. The third discrimination, job and occupational discrimination, is the situation that some occupational groups are closed to some disadvantaged population groups due to employers or customers with discriminatory preferences. The last discrimination type, human capital discrimination, is the situation where companies with discriminatory preferences use human capital investments that enable the labor to get better promotion and wages in favor of some employment groups again due to social prejudices (McConnell, Brue and Macpherson, 2013).
As mentioned above, the real wages in neoclassical economics is set at the point where the labor is equal to the marginal physical efficiency and firms maximize their profits. Since the firm cannot maximize its profits in all cases where this equality is not achieved, it will not be able to compete with its rivals in the long-term. In gender-based wage discrimination, since the employer, as a social prejudice, considers that the female labor as will work more inefficiently, for this reason, the employer will tend to pay lower wages to the female labor for profit maximization. However, when the female worker who works as efficiently as a male worker receives lower wages, the real wages will be lower than the marginal physical productivity and thus, distribution and production efficiency of the company will be impaired.

For all these reasons, firms with gender-based wage discrimination preferences not only lose their production efficiency, but also impair the distribution efficiency of production factors in the country. Although the firms adopting such a behavior increase their income in the short- term, they lose due to disrupting the long-term distribution efficiency (Borjas, 2010). On the other hand, due to companies with discriminatory preferences, the labor peace in the country is deteriorating, disadvantaged groups are created within the population and income distribution is disrupted (Jacobsen and Skillman, 2004).

According to the ILO (2018) report, women earn approximately $20 \%$ less than men across the World. At both national and international levels, the gender wage gap is a widely used indicator of gender inequality. The United Nations Sustainable Development Goal, target 8.5, emphasizes "equal pay for work of equal value", and "average hourly earnings of female and male employees" (UN, 2017). Equal Pay International Coalition (EPIC), is aimed at equal pay for women and men, and interprets the progress towards this target. Figure 1 shows the mean gender wage gap based on monthly earnings, for up to 65 countries; estimated by ILO (2018).

The first taking attention from figure 1 is that the gender wage gap is estimated as a positive value. Only two of 65 countries show negative gender wage gaps, it means that men earn more than women. For example, in the case of Turkey, the mean monthly gender wage gap is $9.3 \%$, while around the world monthly gender wage gap is $20.5 \%$. Even if the Turkey's gender wage gap is below the world average, the $9.3 \%$ provide evidence of an overall wage gap in favour of men. 

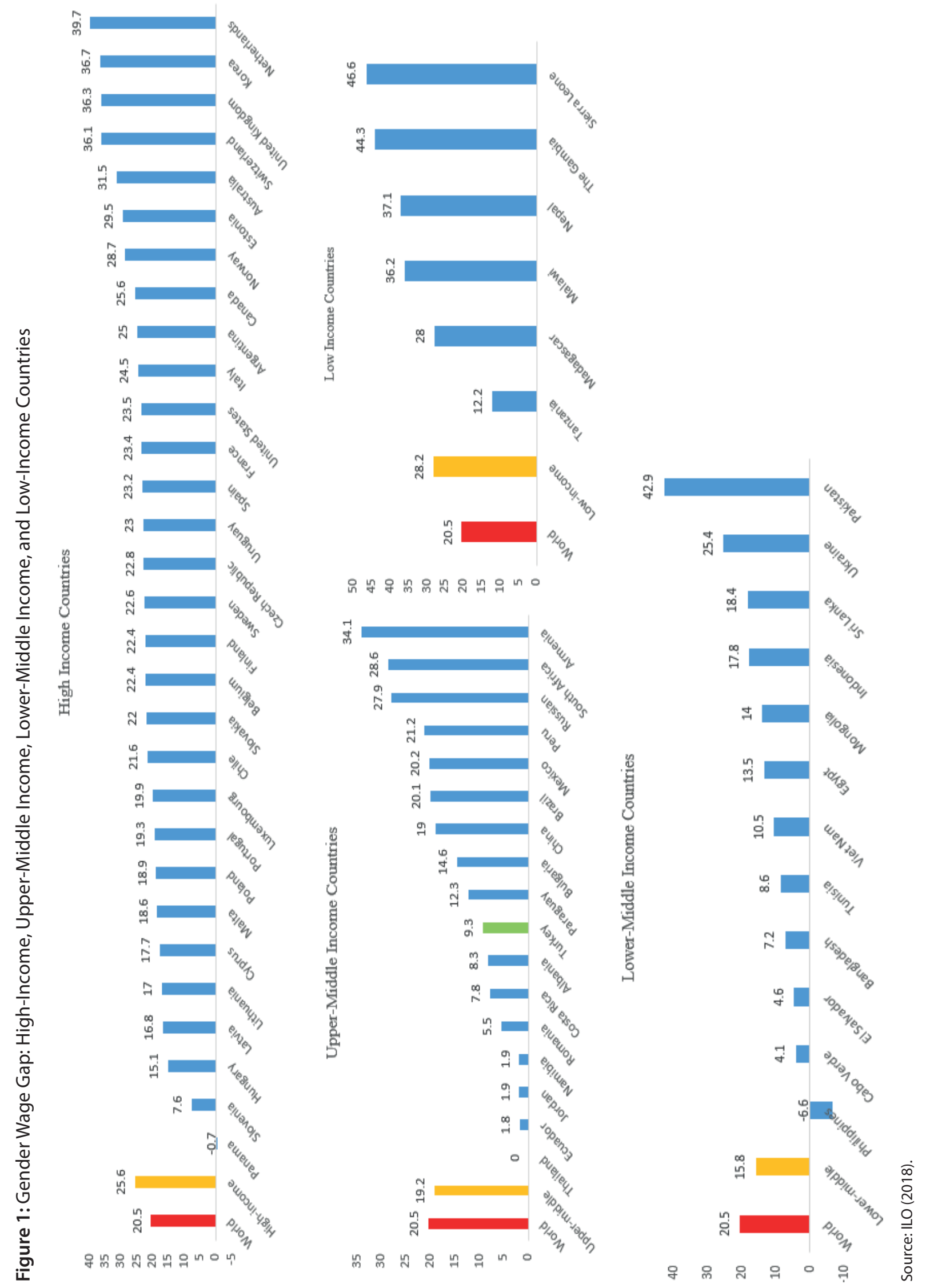


\section{Data and Method}

This study presents determination of gender-based wage differentials in Turkey by estimating expanded Mincerian wage equations. Machado-Mata decomposition method that uses the quantile regression method is employed in the analysis performed by using micro data set of 2017 Household Budget Survey, published by TurkStat.

\section{Data}

The Household Budget Survey provides information on socio-economic structures, standards of living, and consumption patterns of the households and also it is used to socio-economic analyses. Indicators of consumption expenditure were obtained by 1296 sample households changing every month and 15.552 sample households for a year between $1^{\text {st }}$ January and $31^{\text {st }}$ December 2017. The estimation level of $2017 \mathrm{Hou}-$ sehold Budget Survey is whole Turkey; it is not possible to make estimations on urban, rural and regional basis because of sampling design of the survey. The first flow sampling frame for 2017 Household Budget Survey was obtained from National Address Database and the final sampling unit was household live at the address. Stratified two-stage cluster sampling method was used. For 2017 Household Budget Survey, the non-response rate was $21.8 \%$ for overall Turkey.

Table 1: Descriptive Statistics of Variables

\begin{tabular}{|c|c|c|c|c|c|}
\hline Variable & Observation & Mean & Standart Deviation & Min & Max \\
\hline Logwage & 10,073 & 9.620487 & 1.012743 & 3.688879 & 12.94801 \\
\hline Gender & 10,073 & 0.289983 & 0.4537768 & 0 & 1 \\
\hline Men & $7152(\% 71)$ & & & & \\
\hline Women & 2921 (\%29) & & & & \\
\hline Educaiton & 10,073 & 2.572918 & 1.536254 & 0 & 6 \\
\hline Non-graduate & $427(\% 4.24)$ & & & & \\
\hline Primary school & $2734(\% 27.14)$ & & & & \\
\hline Secondary school & $2062(\% 20.47)$ & & & & \\
\hline High school & $2290(\% 22.73)$ & & & & \\
\hline 2-3 years of university & $791(\% 7.85)$ & & & & \\
\hline 4-6 years college & $1589(\% 15.77)$ & & & & \\
\hline Master and PhD & $180(\% 1.79)$ & & & & \\
\hline Experience & 10,073 & 7.344088 & 8.461327 & 0 & 70 \\
\hline Employment & 10,073 & 0.933883 & 0.2484994 & 0 & 1 \\
\hline Part-time & $666(\% 6.6)$ & & & & \\
\hline Full-time & 9407 (\%93.40) & & & & \\
\hline Household head & 10,073 & 0.544326 & 0.498056 & 0 & 1 \\
\hline Yes & $5483(\% 54.43)$ & & & & \\
\hline No & $4590(\% 54.43)$ & & & & \\
\hline Marital status & 10,073 & 0.709719 & 0.4539145 & 0 & 1 \\
\hline Married & $7149(\% 70.97)$ & & & & \\
\hline Other cases & $2924(\% 70.97)$ & & & & \\
\hline Family size & 10,073 & 4.078924 & 1.855863 & 1 & 19 \\
\hline Household with children & 10,073 & 0.829247 & 0.3763121 & 0 & 1 \\
\hline Yes & $8353(\% 82.92)$ & & & & \\
\hline No & $1720(\% 17.08)$ & & & & \\
\hline
\end{tabular}


Descriptive statistics of variables are given in Table 1. The annual cash wage was taken as a dependent variable. The annual earnings of women were 19.600 $\mathrm{TL}$, while those of men were $23.453 \mathrm{TL}$. Women earned about $16.4 \%$ less than men according to 2017 Turkey's Household Budget Survey. The education variable referred to categorical data by the twelve type of schools in the data set; we defined as seven categories (non-graduate, primary school, secondary school, high school, 2-3 years of university, 4-6 years college, master, and $\mathrm{PhD}$ ) in the analysis. The experience variable was defined as working years at the current job; the average experience of women were 7.2 years, while those of men were 8.4 years. We also included to individuals who were working as full-time or part-time employees. The incidence of part-time work is higher among women than among men; $12.1 \%$ of women employees but only $4.3 \%$ of men employees are part-time workers. Household headship status are overwhelmingly favour of men; males are household heads in $93.6 \%$ of households. Marital status and household with children are also binary variables. The average household size is 4.08 according to 2017 Turkey's Household Budget Survey. Our sample consisted of 10073 observations. Distribution of gender, wages and experience by education level is presented in Table 2.

Table 2 reveals that there were very few people with vocational or technical secondary school and 5- and 6-year college education, and most individuals were on a primary education level. After the high school education level, both men and women's wages increased. The level of education and wages were both increasing.

\section{Method}

Mincer (1974), expanded his study in 1958, focused on human capital that expresses the investment made by the individual. The Mincer wage equation includes human capital measures to assess wage inequality. According to Mincer (1974), the most critical factor of human capital is education; thus, the Mincerian earnings equation is a single-equation model that explains wage as a function of year of schooling, experience and experience squared. The model is:

$$
\log \left(\text { Wage }_{i}\right)=\beta_{0}+\beta_{1} \text { Scholling }_{i}+\beta_{2} \text { Experience }_{i}+\beta_{3} \text { Experience }_{i}^{2}+\varepsilon_{i}
$$

Table 2: Distribution of Gender, Wages and Experience by Education Level, 2017, Turkey

\begin{tabular}{lllllll}
\hline \multirow{2}{*}{ Educational level } & \multicolumn{2}{c}{ Gender (Number) } & $\begin{array}{l}\text { Average Annual } \\
\text { Wage (TL) }\end{array}$ & \multicolumn{2}{c}{$\begin{array}{l}\text { Average Experience } \\
\text { (Years) }\end{array}$} \\
\cline { 2 - 7 } & Women & Men & Women & Men & Women & Men \\
\hline Non-graduate & 206 & 221 & 9151.34 & 13897 & 6.67 & 7.67 \\
\hline Primary school (5 years) & 742 & 1,992 & 10543.04 & 17365.49 & 5.59 & 9.55 \\
\hline Secondary school & 230 & 821 & 9757.478 & 17149 & 3.2 & 6.43 \\
\hline Vocational or technical secondary school & 3 & 34 & 12383.33 & 18195.38 & 8.67 & 5.62 \\
\hline Primary school (8 years) & 175 & 799 & 11068.63 & 15783.3 & 2.38 & 3.46 \\
\hline High school & 289 & 856 & 16286.23 & 22149.4 & 4.81 & 7.74 \\
\hline Vocational or technical high school & 265 & 880 & 16222.72 & 22802.44 & 5.08 & 7.04 \\
\hline 2-3 years of university & 270 & 521 & 21266.91 & 29608.6 & 6.82 & 9.18 \\
\hline 4 years college, faculty & 642 & 876 & 30769.21 & 38917.97 & 8.04 & 9.43 \\
\hline 5, 6 years college, faculty & 30 & 41 & 42144.67 & 49764.05 & 9.77 & 6.24 \\
\hline Master & 55 & 74 & 40414.42 & 54851.58 & 9.58 & 9.68 \\
\hline PhD & 14 & 37 & 59945.71 & 87527.57 & 16 & 18.59 \\
\hline Source & & & & & & \\
\hline
\end{tabular}

Source: TurkStat (2017). 
In estimating the wage functions, empirical models such as 'basic Mincer earnings equation' and 'expanded Mincer earnings equations' are applied to the human capital theory (Assaad (1997), Ali (2002), Dewen, Fang, and Guoqing (2010), Nour (2011), Huy (2020), Zhou, Zhao, Chou, and Leivang (2019), Busso, Muñoz, and Montaño (2020)). In this paper, we use an expanded Mincerian function to jointly observe the returns to different types of social levels and skills. Some variables are incorporated in the expanded Mincer equation in order to control socio-economic bias among individuals that may influence the earnings. The expanded earnings function converts the continuous variable of years of schooling into a categorical variables (Psacharopoulos, 1994:1325). Consider impacts of socioeconomic factors $\left(A_{i}\right)$ on the earnings differences, expanded Mincer earnings equations should take the form of:

$$
\log \left(\text { Wage }_{i}\right)=\beta_{0}+\beta_{1} \text { Scholling }_{i}+\beta_{2} \text { Experience }_{i}+\beta_{3} \text { Experience }_{i}^{2}+\beta_{4} A_{i}+\varepsilon_{i}
$$

In the equation (2), $A_{i}$ denotes the explanatory variables including full-time employee, head of household, married, family size, having children. We try to keep the incorporation of explanatory variables as consistent as possible the Household Budget Survey data sets.

García, Hernández and López-Nicolás (2001) hypothesized that there was a gender-based wage differential in Spain and analyzed the wage distributions according to the characteristics with the quantile regression method. In their study, they found wage differentials at one point rather than at quantiles. Gardeazabal and Ugidos (2005), on the other hand, extended Oaxaca's scalar measure to any quantile of the distribution of wages, and using the same Spanish data set, they made analysis with quantile regression by concentrating on differences in returns of certain characteristics of individuals. The results obtained from this study are in contradiction with the study of García Hernández and López-Nicolás (2001); García, Hernández, and López-Nicolás (2001) found that the differences in returns of characteristics increases at the distribution of wages, while Gardeazabal and Ugidos (2005) found that it decreases. In these mentioned studies, the averages of the dependent variable were taken as basis and they were insufficient to explain the differences between the two distributions. Even if the characteristics of men and women would be the same for the selected sample, their variances would not be the same, and the variance of men would be higher in the distribution of the dependent variable. For this very reason, Machado and Mata (2005) proposed an alternative method of decomposition that combines the quantile regression and bootstrap approaches to enable the counterfactual density functions (Heinze, 2010: 4).

The quantile regression method produces an estimation for different quantiles. The quantile regression method may be used without making the normality assumption. The quantile regression method as introduced by Koenker and Bassett (1978) uses a linear model for conditional quantiles, while the ordinary least squares method is just for conditional means. Quantile regression estimates conditional quantile functions including the quantiles of the conditional distribution of the response variable. The quantile regression method is appropriate for skewed distribution that is often associated with wage or income inequality (Koenker and Hallock, 2001: 143). Therefore, different methods are needed to measure issues such as income inequality. This is because the Machado-Mata decomposition method is an extension of the Oaxaca (1973) and Blinder (1973) decomposition method for quantile regression. These decomposition methods analyze whether there is a difference in the wages of individuals who have the same characteristics based on the independent variables determining productivity and qualification. In decomposition methods, wage regressions are estimated for samples of men and women. These methods allow counter-factual analysis. So, the estimated wage differentials are decomposed into two components: individuals' characteristics (productivity and skill qualification) and gender-based wage differentials. Thus, one may determine whether there is a gender-based wage differential. Oaxaca and Blinder assume that the characteristic returns of individuals are mutually interchangeable; this is referred to as counter-factual analysis in the literature. These decompositions are not only gender-oriented but are also used to discriminate based on race, religion, labor market, sector, state or region, etc. Discrimination in the labor market may occur in different ways, and each of them has adverse effects on the economy, firms and individuals, especially on deterioration of income distribution. Wage discrimination, which is one of the discrimination types of the labor market, is 
considered as lower wages of disadvantaged groups due to social prejudices regardless of the productivity of the employees. Gender-based wage discrimination is one of the most common and often severe problems in all economies.
We can rewrite the equation (2) for the quantile regression as follows:

$$
\begin{aligned}
& \log \text { Wage }_{\theta i}=\beta_{\theta 0}+\beta_{\theta 1} \text { scholling }_{i}+\beta_{\theta 2} \text { experience }_{i}+\beta_{\theta 3} \text { experience }_{i}^{2}+\beta_{\theta 4} A_{i}+\varepsilon_{\theta i} \\
& \log W_{a g e_{\theta}^{m}}=X^{m} \beta_{\theta}^{m}+\varepsilon_{\theta}^{m} \\
& \log W_{a g}^{w}=X^{w} \beta_{\theta}^{w}+\varepsilon_{\theta}^{w}
\end{aligned}
$$

$X, \varepsilon$ and $\theta$ denote independent variables, the error term, and the quantile, respectively. We can write men $(m)$ and women's $(w)$ wage models as follows:

Because of $E\left(\varepsilon_{\theta i} \mid X\right)=0$ equation (3) can be written as follows:

$$
\begin{aligned}
& \log \left(\overline{W a g e}_{\theta}^{m}\right)=\bar{X}^{m} \hat{\beta}_{\theta}^{m} \\
& \log \left(\overline{W a g e}_{\theta}^{w}\right)=\bar{X}^{w} \hat{\beta}_{\theta}^{w}
\end{aligned}
$$

In the methodology of the decomposition, samples of men and women are estimated with the quantile regression and the coefficient vector, $\hat{\beta}_{\theta}^{w}$ and, $\hat{\beta}_{\theta}^{m}$ obtained for each quantile. Random samples are taken from the estimated coefficient vector of the samples of men and women, and then, coefficients are replaced with each other, so that counter-factual analysis can be conducted. $\bar{X}^{m} \hat{\beta}_{\theta}^{w}$ and $\bar{X}^{w} \hat{\beta}_{\theta}^{m}$ values are calculated for each quantile. We can write the women's counter-factual wage function as follow:

$$
\log \left(\overline{\operatorname{Wage}}_{\theta}^{m}\right)-\log \left(\overline{\operatorname{Wage}}_{\theta}^{w}\right)=\left(\bar{X}^{m}-\bar{X}^{w}\right) \hat{\beta}_{\theta}^{m}+\bar{X}^{w}\left(\hat{\beta}_{\theta}^{m}-\hat{\beta}_{\theta}^{w}\right)
$$

The basis of the counter-factual analysis is as if women (men) had men's (women's) wage-generating characteristics, but her/his wage is as women (men). $\left(\bar{X}^{m}-\bar{X}^{w}\right) \hat{\beta}_{\theta}^{m}$ explains part of the equation (6) and denotes the contribution of individuals' wage-generating characteristics on the wage gap. Explained wage differentials are due to the productivity of individuals in the labor market. Individuals who have higher levels of human capital should be paid more, and the expected wage differentials in the market would be estimated in this part. Therefore, this part is multiplied by the parameter for male $\left(\hat{\beta}_{\theta}^{m}\right)$. Let the average characteristics of all men and women in the data set be the same, then the explained part of the equation takes the value of zero. $\bar{X}^{w}\left(\hat{\beta}_{\theta}^{m}-\hat{\beta}_{\theta}^{w}\right)$ is the unexplained part of this equation and denotes gender-based wage differentials. $\bar{X}^{w}\left(\hat{\beta}_{\theta}^{m}-\hat{\beta}_{\theta}^{w}\right)$ indicates the difference in the wages of the individuals who have the same ability of wage-generating characteristics but different gender. This component is taken as wage discrimination.

Following the Machado-Mata method, the literature has continued to progress with the subject. Melly (2005) extended this study by determining the asymptotic distribution of the estimators in the Machado-Mata method. Martinez-Sanchis Mora and Kandemir (2012), on the other hand, extended the methodologies developed by Machado-Mata and Melly, for the endogeneity of schooling decisions using a control function approach.

\section{Empirical Findings}

The model is estimated using the data set of the 2017 Household Budget Survey conducted by the TurkStat. Quantile regression, ordinary least squares (OLS) regression and Machado-Mata decomposition analysis were done in Stata version 15.0. Using the Mincerian wage equations, the quantile regression estimates are given in Table 3.

Almost all coefficients reported here are statistically significant, and the wage increases with education level and experience, which is in accordance with expectations. Table 3 suggests that the wage differentials in the lower part of the education distribution are much higher than the ones in the upper part. The increase in wages for individuals with low education will be higher than those with higher education in Turkey. The same comments may also apply to the experience, full-time employee, head of household, married, family size and children variables. The return of these variables decreases in the upper parts of the distribution. In both education level and experience variables, the coefficients towards upper distribution tend to remain fixed. 
Table 3: Quantile Regression Results

\begin{tabular}{|c|c|c|c|c|c|c|c|}
\hline $\begin{array}{l}\text { Independent } \\
\text { Variables }\end{array}$ & 0.05 & 0.1 & 0.25 & 0.5 & 0.75 & 0.9 & OLS \\
\hline \multicolumn{8}{|l|}{$\mathrm{n}=10073$} \\
\hline \multicolumn{8}{|l|}{ Education (Non-graduate $=0$ ) } \\
\hline \multirow[t]{2}{*}{ Primary school } & $-0.456^{*}$ & -0.052 & $0.126^{* *}$ & $0.162^{*}$ & $0.159^{*}$ & $0.116^{*}$ & $0.079 * * *$ \\
\hline & 0.002 & 0.695 & 0.048 & 0.000 & 0.000 & 0.008 & 0.057 \\
\hline \multirow[t]{2}{*}{ Secondary school } & 0.238 & $0.400^{*}$ & $0.293^{*}$ & $0.287^{*}$ & $0.290^{*}$ & $0.208^{*}$ & $0.280^{*}$ \\
\hline & 0.120 & 0.003 & 0.000 & 0.000 & 0.000 & 0.000 & 0.000 \\
\hline \multirow[t]{2}{*}{ High school } & $0.621^{*}$ & $0.664^{*}$ & $0.516^{*}$ & $0.457^{*}$ & $0.421^{*}$ & $0.412^{*}$ & $0.496^{*}$ \\
\hline & 0.000 & 0.000 & 0.000 & 0.000 & 0.000 & 0.000 & 0.000 \\
\hline \multirow[t]{2}{*}{ 2-3 years of university } & $1.011^{*}$ & $0.978^{*}$ & $0.783^{*}$ & $0.687^{*}$ & $0.665^{*}$ & $0.603^{*}$ & $0.754^{*}$ \\
\hline & 0.000 & 0.000 & 0.000 & 0.000 & 0.000 & 0.000 & 0.000 \\
\hline \multirow[t]{2}{*}{ 4-6 years college } & $1.315^{*}$ & $1.235^{*}$ & $0.975^{*}$ & $0.899^{*}$ & $0.869^{*}$ & $0.882^{*}$ & $1.010^{*}$ \\
\hline & 0.000 & 0.000 & 0.000 & 0.000 & 0.000 & 0.000 & 0.000 \\
\hline \multirow[t]{2}{*}{ Master and PhD } & $1.446^{*}$ & $1.435^{*}$ & $1.211^{*}$ & $1.217^{*}$ & $1.328^{*}$ & $1.363^{*}$ & $1.383^{*}$ \\
\hline & 0.000 & 0.000 & 0.000 & 0.000 & 0.000 & 0.000 & 0.000 \\
\hline \multirow[t]{2}{*}{ Experience } & $0.166^{*}$ & $0.150^{*}$ & $0.096^{*}$ & $0.048^{*}$ & $0.038^{*}$ & $0.035^{*}$ & $0.070^{*}$ \\
\hline & 0.000 & 0.000 & 0.000 & 0.000 & 0.000 & 0.000 & 0.000 \\
\hline \multirow[t]{2}{*}{ Experience $^{2}$} & $-0.006^{*}$ & $-0.005^{*}$ & $-0.003^{*}$ & $-0.001^{*}$ & $-0.001^{*}$ & $-0.001^{*}$ & $-0.002^{*}$ \\
\hline & 0.000 & 0.000 & 0.000 & 0.000 & 0.000 & 0.000 & 0.000 \\
\hline \multirow[t]{2}{*}{ Fulltime } & $1.532^{*}$ & $1.521^{*}$ & $1.629^{*}$ & $1.279^{*}$ & $0.816^{*}$ & $0.508^{*}$ & $1.164^{*}$ \\
\hline & 0.000 & 0.000 & 0.000 & 0.000 & 0.000 & 0.000 & 0.000 \\
\hline \multirow[t]{2}{*}{ Household head } & $0.779^{*}$ & $0.581^{*}$ & $0.321^{*}$ & $0.235^{*}$ & $0.223^{*}$ & $0.269^{*}$ & $0.377^{*}$ \\
\hline & 0.000 & 0.000 & 0.000 & 0.000 & 0.000 & 0.000 & 0.000 \\
\hline \multirow[t]{2}{*}{ Married } & $0.453^{*}$ & $0.368^{*}$ & $0.209^{*}$ & $0.134^{*}$ & $0.104^{*}$ & $0.083^{*}$ & $0.178^{*}$ \\
\hline & 0.000 & 0.000 & 0.000 & 0.000 & 0.000 & 0.000 & 0.000 \\
\hline \multirow[t]{2}{*}{ Family size } & $-0.041^{* *}$ & $-0.033^{* *}$ & $-0.041^{*}$ & $-0.025^{*}$ & $-0.016^{*}$ & -0.004 & $-0.019 *$ \\
\hline & 0.025 & 0.043 & 0.000 & 0.000 & 0.000 & 0.412 & 0.000 \\
\hline \multirow[t]{2}{*}{ Children } & $0.190^{* *}$ & 0.100 & $0.086^{* *}$ & $0.060^{*}$ & $0.041^{* *}$ & 0.016 & $0.070^{*}$ \\
\hline & 0.031 & 0.197 & 0.022 & 0.002 & 0.014 & 0.525 & 0.004 \\
\hline \multirow[t]{2}{*}{ Constant } & $5.107^{*}$ & $5.715^{*}$ & $6.820^{*}$ & $7.800^{*}$ & $8.568^{*}$ & $9.111^{*}$ & $7.517^{*}$ \\
\hline & 0.000 & 0.000 & 0.000 & 0.000 & 0.000 & 0.000 & 0.000 \\
\hline$R^{2}$ & 0.269 & 0.289 & 0.274 & 0.244 & 0.280 & 0.266 & 0.394 \\
\hline \multicolumn{8}{|c|}{$*{ }^{* *}$ and ${ }^{* * *}$ indicate the level of significance at $1 \%, 5 \%$ and $10 \%$, respectively. } \\
\hline$p$ values are italic. & & & & & & & \\
\hline
\end{tabular}

Source: Authors' estimates. ${ }^{1}$

The first step of the Machado-Mata decomposition is to apply quantile regression on the datasets of men and women separately. The quantile regression results are given in Table 4.

\footnotetext{
${ }^{1}$ To provide convenience, $0.05,0.1,0.25,0.5,0.75$ and 0.9 quantiles are given in the table. The others are available upon request.
} 
Table 4: Quantile Regression Results by Gender

\begin{tabular}{|c|c|c|c|c|c|c|c|}
\hline \multicolumn{8}{|l|}{ Quantile } \\
\hline $\begin{array}{l}\text { Independent } \\
\text { Variables }\end{array}$ & 0.05 & 0.1 & 0.25 & 0.5 & 0.75 & 0.9 & OLS \\
\hline \multicolumn{8}{|l|}{ Women $(n=2921)$} \\
\hline \multicolumn{8}{|l|}{ Education (Non-graduate=0) } \\
\hline \multirow[t]{2}{*}{ Primary school } & $-0.575^{* *}$ & $-0.32 * * *$ & -0.004 & $0.176^{*}$ & $0.226^{*}$ & 0.082 & 0.039 \\
\hline & 0.033 & 0.095 & 0.976 & 0.006 & 0.000 & 0.148 & 0.596 \\
\hline \multirow[t]{2}{*}{ Secondary school } & 0.203 & 0.040 & 0.113 & $0.318^{*}$ & $0.297^{*}$ & $0.136^{* *}$ & $0.203^{* *}$ \\
\hline & 0.491 & 0.848 & 0.413 & 0.000 & 0.000 & 0.028 & 0.011 \\
\hline \multirow[t]{2}{*}{ High school } & $0.702^{* *}$ & $0.756^{*}$ & $0.581^{*}$ & $0.557^{*}$ & $0.440^{*}$ & $0.321^{*}$ & $0.571^{*}$ \\
\hline & 0.014 & 0.000 & 0.000 & 0.000 & 0.000 & 0.000 & 0.000 \\
\hline \multirow[t]{2}{*}{$2-3$ years of university } & $0.974^{*}$ & $1.081^{*}$ & $0.851^{*}$ & $0.756^{*}$ & $0.674^{*}$ & $0.601^{*}$ & $0.822^{*}$ \\
\hline & 0.003 & 0.000 & 0.000 & 0.000 & 0.000 & 0.000 & 0.000 \\
\hline \multirow[t]{2}{*}{ 4-6 years college } & $1.670^{*}$ & $1.440^{*}$ & $1.101^{*}$ & $1.023^{*}$ & $0.937^{*}$ & $0.870^{*}$ & $1.148^{*}$ \\
\hline & 0.000 & 0.000 & 0.000 & 0.000 & 0.000 & 0.000 & 0.000 \\
\hline \multirow[t]{2}{*}{ Master and PhD } & $1.569^{*}$ & $1.553^{*}$ & $1.320^{*}$ & $1.231^{*}$ & $1.328^{*}$ & $1.308^{*}$ & $1.411^{*}$ \\
\hline & 0.001 & 0.000 & 0.000 & 0.000 & 0.000 & 0.000 & 0.000 \\
\hline \multirow[t]{2}{*}{ Experience } & $0.232^{*}$ & $0.245^{*}$ & $0.162^{*}$ & $0.073^{*}$ & $0.044^{*}$ & $0.045^{*}$ & $0.103^{*}$ \\
\hline & 0.000 & 0.000 & 0.000 & 0.000 & 0.000 & 0.000 & 0.000 \\
\hline \multirow[t]{2}{*}{ Experience $^{2}$} & $-0.008^{*}$ & $-0.009^{*}$ & $-0.005^{*}$ & $-0.002^{*}$ & $-0.001^{*}$ & $-0.001^{*}$ & $-0.003^{*}$ \\
\hline & 0.000 & 0.000 & 0.000 & 0.000 & 0.000 & 0.000 & 0.000 \\
\hline \multirow[t]{2}{*}{ Fulltime } & $1.515^{*}$ & $1.370^{*}$ & $1.478^{*}$ & $1.254^{*}$ & $0.841^{*}$ & $0.496^{*}$ & $1.126^{*}$ \\
\hline & 0.000 & 0.000 & 0.000 & 0.000 & 0.000 & 0.000 & 0.000 \\
\hline \multirow[t]{2}{*}{ Household head } & 0.309 & 0.206 & 0.159 & $0.167^{*}$ & $0.110^{*}$ & $0.111^{* *}$ & $0.218^{*}$ \\
\hline & 0.187 & 0.217 & 0.147 & 0.003 & 0.003 & 0.024 & 0.001 \\
\hline \multirow[t]{2}{*}{ Married } & $0.607^{*}$ & $0.355^{*}$ & $0.182^{* *}$ & $0.133^{*}$ & $0.089^{*}$ & 0.052 & $0.197^{*}$ \\
\hline & 0.000 & 0.001 & 0.012 & 0.000 & 0.000 & 0.110 & 0.000 \\
\hline \multirow[t]{2}{*}{ Family size } & -0.064 & -0.022 & $-0.045^{* *}$ & $-0.027^{* *}$ & $-0.033^{*}$ & $-0.01^{* * *}$ & $-0.03^{* *}$ \\
\hline & 0.179 & 0.515 & 0.044 & 0.016 & 0.000 & 0.092 & 0.019 \\
\hline \multirow[t]{2}{*}{ Children } & -0.039 & -0.088 & 0.024 & -0.011 & 0.030 & 0.036 & -0.004 \\
\hline & 0.839 & 0.517 & 0.793 & 0.803 & 0.320 & 0.364 & 0.932 \\
\hline \multirow[t]{2}{*}{ Constant } & $5.051^{*}$ & $5.674^{*}$ & $6.728^{*}$ & $7.679^{*}$ & $8.519^{*}$ & $9.105^{*}$ & $7.439^{*}$ \\
\hline & 0.000 & 0.000 & 0.000 & 0.000 & 0.000 & 0.000 & 0.000 \\
\hline$R^{2}$ & 0.257 & 0.300 & 0.322 & 0.282 & 0.321 & 0.299 & 0.422 \\
\hline \multicolumn{8}{|l|}{ Men $(n=7152)$} \\
\hline Primary school & $-0.408^{* * *}$ & -0.005 & 0.097 & $0.085^{* *}$ & $0.088^{* *}$ & $0.112^{* * *}$ & 0.031 \\
\hline & 0.090 & 0.970 & 0.195 & 0.042 & 0.027 & 0.056 & 0.550 \\
\hline \multirow[t]{2}{*}{ Secondary school } & 0.164 & $0.338^{* *}$ & $0.244^{*}$ & $0.185^{*}$ & $0.205^{*}$ & $0.180^{*}$ & $0.197^{*}$ \\
\hline & 0.500 & 0.016 & 0.001 & 0.000 & 0.000 & 0.002 & 0.000 \\
\hline High school & $0.504^{* *}$ & $0.527^{*}$ & $0.390^{*}$ & $0.357^{*}$ & $0.359^{*}$ & $0.375^{*}$ & $0.392^{*}$ \\
\hline
\end{tabular}




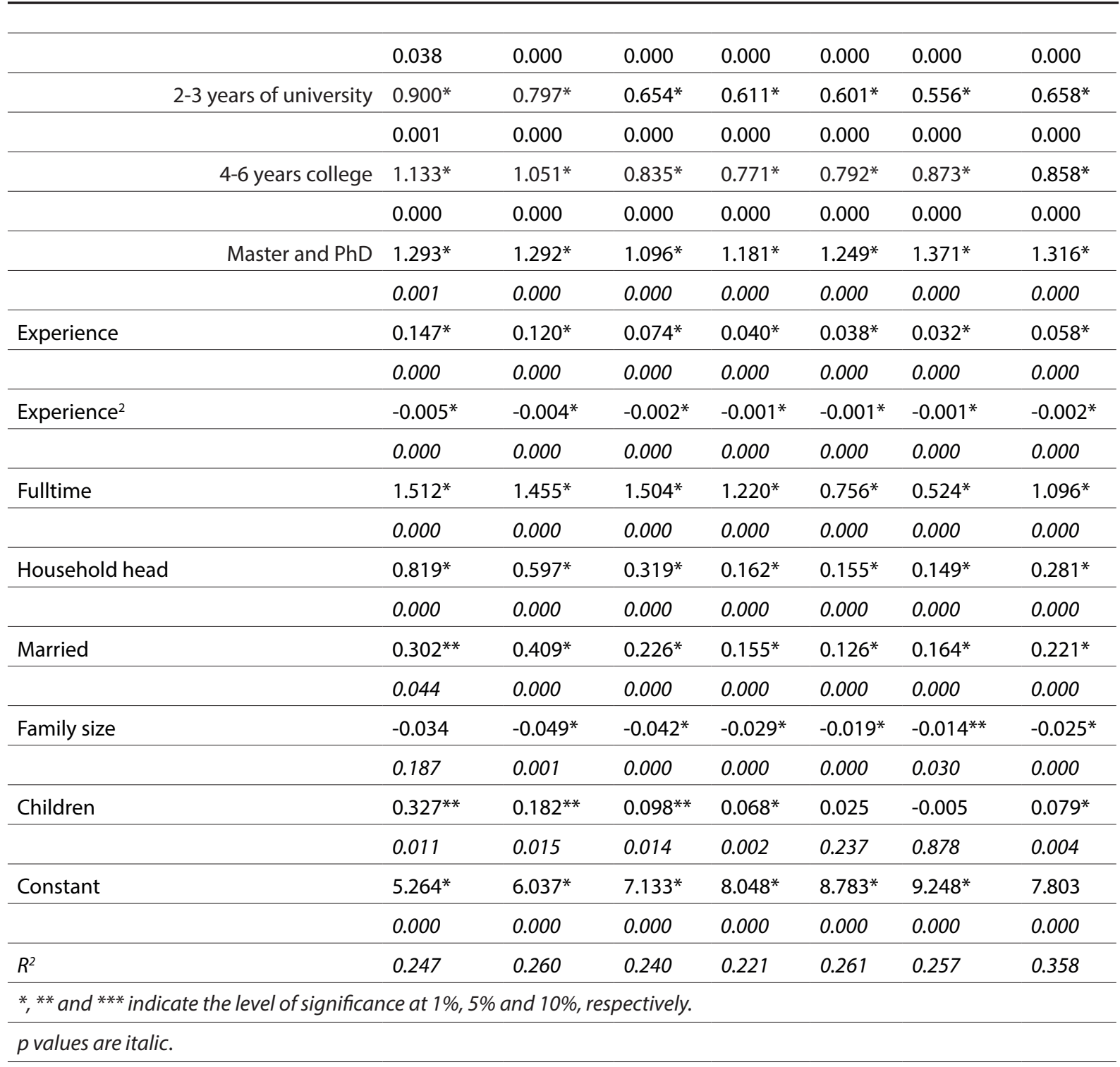

Source: Authors' estimates. ${ }^{2}$

Table 4 reports that the return of education and experience variables on wages is higher for women. It is observed that the high return of education is a lower quantile for both men and women and tends to decrease in the upper part of the distribution. The high return of experience on wages is realized in the upper part of the distribution for men and women. These results are consistent with Table 3. While other variables were generally similar for men and women, the variable 'having children at home' was found to be insignificant for women in all quantiles and OLS.

The decomposition results are based on 1000 bootstrap repetitions ${ }^{3}$. Wage differentials are presented as raw, total, explained and unexplained wage differen- tials in Table 5. Negative coefficients show that wages are disadvantageous to women. If the coefficients are zero, this means that there are no wage differentials and differences. Total wage differentials are the sum of the difference between the explained and unexplained wage. Explained wage differentials represent the characteristics of wage differentials, namely non-gender-based difference. The unexplained part shows the gender-based part of the wage gap, a difference that is not related to the human capital of individuals. The results of the decomposition are given in Table 5 .

${ }^{2}$ To provide convenience, $0.05,0.1,0.25,0.5,0.75$ and 0.9 quantiles are given in the table. The others are available upon request. ${ }^{3}$ Detailed bootstrap results in detail are available upon request. 
Table 5: Machado-Mata Decomposition Results

\begin{tabular}{|c|c|c|c|c|}
\hline Quantile & $\begin{array}{l}\text { Raw (observed) } \\
\text { wage difference }\end{array}$ & $\begin{array}{c}\text { Total wage } \\
\text { difference } \\
{\left[\bar{W}_{Q}^{m}-\bar{W}_{Q}^{w}\right]}\end{array}$ & $\begin{array}{c}\text { Explained (characteristic) } \\
\text { wage difference } \\
{\left[\left(\bar{X}^{m}-\bar{X}^{w}\right) \hat{\beta}_{Q}^{m}\right]}\end{array}$ & $\begin{array}{l}\text { Unexplained (gender- } \\
\text { based) wage difference } \\
\qquad\left[\left(\bar{X}^{w} \hat{\beta}_{Q}^{m}-\hat{\beta}_{Q}^{w}\right)\right]\end{array}$ \\
\hline 0.05 & -1.0508 & -0.9925 & -0.5955 & -0.3970 \\
\hline 0.1 & -1.0704 & -0.8814 & -0.5419 & -0.3395 \\
\hline 0.15 & -0.9808 & -0.7837 & -0.4802 & -0.3035 \\
\hline 0.2 & -0.8109 & -0.6662 & -0.4057 & -0.2604 \\
\hline 0.25 & -0.6433 & -0.5575 & -0.3416 & -0.2159 \\
\hline 0.3 & -0.4793 & -0.4720 & -0.2943 & -0.1777 \\
\hline 0.35 & -0.4019 & -0.4061 & -0.2613 & -0.1447 \\
\hline 0.4 & -0.3196 & -0.3547 & -0.2379 & -0.1167 \\
\hline 0.45 & -0.1431 & -0.3193 & -0.2222 & -0.0971 \\
\hline 0.5 & -0.1335 & -0.2920 & -0.2117 & -0.0803 \\
\hline 0.55 & -0.1942 & -0.2702 & -0.2021 & -0.0681 \\
\hline 0.6 & -0.2208 & -0.2487 & -0.1920 & -0.0567 \\
\hline 0.65 & -0.2421 & -0.2238 & -0.1791 & -0.0447 \\
\hline 0.7 & -0.2136 & -0.1971 & -0.1664 & -0.0307 \\
\hline 0.75 & -0.2231 & -0.1708 & -0.1529 & -0.0179 \\
\hline 0.8 & -0.0821 & -0.1416 & -0.1385 & -0.0031 \\
\hline 0.85 & -0.0690 & -0.1129 & -0.1306 & 0.0177 \\
\hline 0.9 & -0.1376 & -0.1028 & -0.1275 & 0.0247 \\
\hline 0.95 & -0.1475 & -0.1143 & -0.1191 & 0.0048 \\
\hline
\end{tabular}

Source: Authors' estimates.

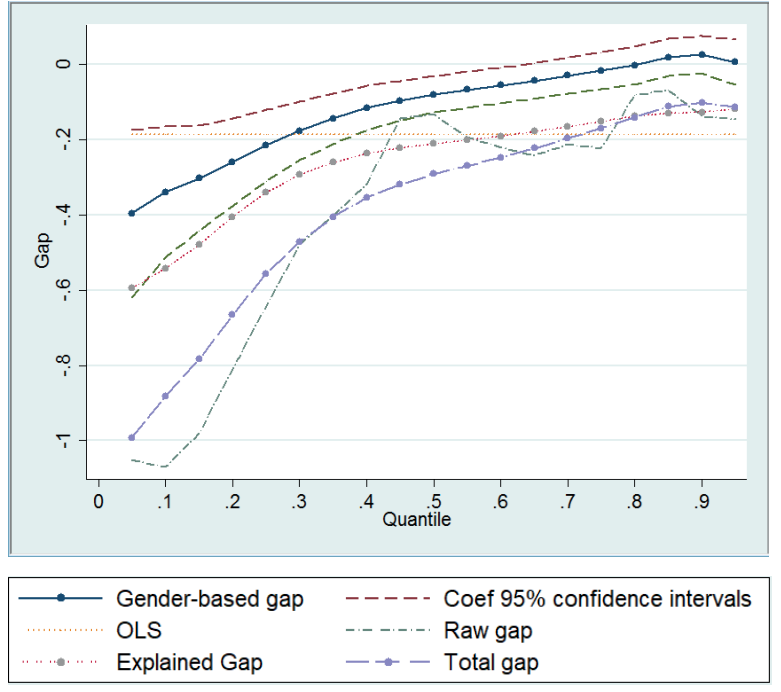

Figure 2: Wage differentials and confidence intervals

As it may be seen in Table 5, the observed wage differentials are quite high in the lower tail of the distribution, and they decrease towards the upper tail of the distribution. This decrease is more clearly observed in the total, explained and unexplained wage difference. While much of the wage difference between men and women in all quantiles are based on independent variables, in other words, characteristics, few depend on the gender-based. The coefficients of the characteristic wage difference are negative; the returns of the characteristics (depends on the independent variable) of men are higher than those of women. However, examining the wage differentials explained, a decrease at quantiles draws attention, and this means that the characteristics of women at high socio-economic levels converge to men and gender-based wage differentials are gradually decreasing. It is noteworthy that, on average, about $70 \%$ of the wage differentials are based on characteristic features and the rest on gender. But, it should not be ignored that the rest of the part, gender-based wage differentials, was also at a considerable amount.

In Turkey, the gender-based wage differentials in the lower tail of the distribution are more extensive, while in the upper tail of the distribution, they tend to be closed up. The gender-based wage differentials are quite high in the lower part of the distribution 
and gradually decrease up to the upper part. This is important for low-income women who are already disadvantaged.

This situation mentioned was shown in Figure 2. Again, it can be clearly seen from Figure 2 that the gender-based and characteristic wage differentials were quite high in the lower parts of the distribution and that these differentials tend to close as the distribution progresses to the upper parts. It stands out that the total wage differentials were equal to the sum of the characteristic and gender-based wage differentials and that the total and characteristic wage differential curves were relatively closer. Another striking point in Figure 2 was the OLS curve. Since it gives condition means-based point estimation, OLS fails to provide information about both the distribution and the source of the mentioned wage differentials.

The findings of this study were consistent with some studies examining gender-based wage differentials, while they were not consistent with others. Dayioglu and Kasnakoglu (1997) concluded that gender-based wage differentials are 64\% against women while Ilkkaracan and Selim (2007) found this rate as $43 \%$ and Cudevill and Gurbuzer (2007) calculated it as $25 \%$ for men in countenance. The studies of Fitzenberger and Kunze (2005) for Germany, Arulampalam et al. (2007) for North European countries and Heinze (2010) for Germany concluded that, in the lower part of the distribution, gender-based wage differentials are higher, and as the quantiles increase, the wage differentials reach a decreasing trend, and the results overlap with this study's results. Albrecht et al. (2003) for Sweden, Gardeazabal and Ugidos (2005) for Spain and Christofides et al. (2013) obtained results that were contrary to those in this study. Tansel and Bircan Bodur (2012) analyzed wage differentials between sectors by gender and emphasized gender wage gap in the private sector in favor of men while no gender-based in the public administration. Aktas and Uysal (2016) did not find gender-based gap at the lower end of the wage distribution at a firm level while we found high in the lower tail of the distribution for nation-wide. ILO (2018), has shown that among high-income countries the gender wage gap tends to widen at the upper end of the distribution, so this result was contrary to those in this study.

\section{Discussion}

This study aimed to explore the gender-based wage differentials in Turkey by using the Machado-Mata decomposition method. It was found that a minor part of the total wage differentials were gender-based, and majority of the total wage differentials depended on the independent variables, which were education, experience and experience squared, full-time employee, head of household, married, family size, having children. But, it should not be ignored that the rest of the part, gender-based wage differentials, was also at a considerable amount.

Not only the observed wage differentials but also the gender-based wage differentials were high in the lower tail of the distribution and low in the distribution's upper tail. This situation is even more challenging for women in low-income groups who are already disadvantaged. According to the explained wage differentials results, the productivity of women in the upper parts of the distribution increased significantly, and this situation slowed down the wage differentials against women even if it did not eliminate the discrimination. The gender-based wage differentials towards the upper part of the distribution were reduced but did not become zero. In conclusion, men earned more than women at every point of distribution. However, women in the low-income group were subject to more gender-based wage differentials than those in the high-income group. Women in Turkey, as a result of increased socio-economic level, obtain two advantages: decrease in gender-based wage differentials and increase in the return of wages.

The reason why women in the low-income group enter the labor market is to contribute to the household as a second income because their husbands are already working (Ozcatal, 2011:28). These women who do not have the concern of being retired or under insurance are employed in jobs that do not require qualifications. Women in low-wage groups in Turkey are employed in informal sectors, especially in the agricultural and textile sectors (ASPM, 2014), and the fact that women work more intensively at low wages and their wages are detached from productivity makes it easier for wage differentials to occur. Non-market discrimination, which is discrimination against women entering the labor market, causes women to work at low wages, where the productivity of women is not essential. So, this leads to a low female labor force participation rate. It would be useful to investigate the reasons that force women to leave the labor market or the sociological factors on why women prefer not to enter the labor market. Besides all these, firms with gender-based wage discrimination preferences keep a population 
that can work efficiently away from production and thus, also cause the production capacity in the country to decrease. Discrimination, experienced particularly in the labor market, has serious implications for the entire economy, primarily for disruption of distribution efficiency. For this reason, monitoring the emergence of wage discrimination in the labor market and being able to measure it accurately is important for policies that ensure economic efficiency.

Since the factors that gender wage gaps varies from country to country and as well as from region to region. Better data that can be regional and sectorial basis estimates and contain more socio-economic variables, is required for developing the right policies and measures. It is also important to determine that workers in the informal economy. The decomposition results show that explain part of the gender wage gap can be explained by productivity of individuals in the labor market, including level of education. It is important to note that saying that gender equality in education or in other spheres should be ensured. ILO's (2018: 97) report shows that motherhood wage gap, is the wage gap between mothers and non-mothers, ranges from $1 \%$ per cent or less in Canada, Mongolia or South Africa to as much as 30\% in Turkey. It should be ensured that women have a fair deal in the workplace or flexible working-time arrangements and provide more kindergarten in the workplaces. 


\section{References}

Aile ve Sosyal Politikalar Bakanligi Kadinin Statusu Genel Mudurlugu (ASPM). (2014). Turkiye'de Kadin Isgucu Profili Istatistiklerinin Analizi. Ankara.

Akcomak, I. and Kasnakoglu Z. (2003). The determinants of earing differentials in Ankara and Istanbul. ODTU Gelisim Dergisi, 30 (1), 1-17.

Akhmedjonov, A. (2012). New Evidence on Pay Gap Between men and Women in Turkey. Economics Letters, 117 (1), 32-34.

Aktas, A. and Uysal, G. (2016). The gender wage gap in Turkey. Marmara Universitesi Iktisadi ve Idari Bilimler Dergisi, 38 (2), 1-19.

Ali, A.A.G. (2002). Building Human Capital for Economic Development in the Arab Countries. Egyptian Center for Economic Studies, http://www.mafhoum.com/press4/115E19.pdf, Access date: 02.01.2020.

Albrecht, J., Bjorklund, A. and Vroman, S. (2003). Is There a Glass Ceiling in Sweden?. Journal of Labor Economics, 21 (1), 145-177.

Albrecht, J., van Vuuren, A. and and Vroman, S. (2009). Counterfactual distributions with sample selection adjustments: econometric theory and an application to the Netherlands. Labor Economics, 16 (4), 383-396.

Andrada, M. J. and Galassi, G. L. (2009). Education, labor market and life quality: A quantitative approach based on Mincer Equations. Retrieved from: http://iussp2009.princeton. edu/papers/93177, Date: 25 October 2018.

Arulampalam, W., Booth, L. A. and Bryan, M. L. (2007). Is There a Glass Ceiling over Europe?. Industrial and Labor Relations Review, 60 (2), 163-186.

Assaad, R. (1997). The Effects of Public Sector Hiring and Compensation Policies on the Egyptian Labor Market. The World Bank Economic Review, 11(1), 85-118.

Azam, M., and Prakash, N. (2010). A Distributional Analysis of the Public-Private Wage Differential in India. Bonn: IZA Discussion Paper Series No: 5132.

Barro, R. J. (1998). Human Capital and Growth in Cross - Country Regressions. USA: Harvard University Press, 1-46.

Becker, G. S. (1962). Investment in human capital: A theoretical analysis. Journal of Political Economy, 70 (5), 9-49.

Becker, G. S. (1974). A Theory of Social Interactions. The Journal of Political Economy, 82 (6), 1063-1093.

Bertrand, M. and Mullainathan, S. (2004). Are Emily and Greg more employable than Lakisha and Jamal? A field experiment on labor market discrimination. The American Economic Review, 94 (4), 991-1013.

Blackaby, D.H., Leslie, D.G., Murphy, P.D. and O'Leary, N.C. (1998). The ethnic wage gap and employment differentials in the 1990s: evidence for Britain. Economics Letters, 58, 97-103.
Blinder, A. (1973). Wage differentials: reduced form and structural estimates. Journal of Human Resources, 8 (4), 436-455.

Blundell, R., Dearden L., Meghir C., and Sianesi, B. (1999). Human Capital Investment: The Returns from Education and Training to the Individual, the Firm and the Economy. Fiscal Studies, 20 (1), 1-23.

Borjas, G. (2010). Labor Economics (5th Edition). United States: McGraw Hill, 236-287; 365-412.

Borowczyk-Martins, D., Bradley, J. and Tarasonis, L. (2017). Racial discrimination in the U.S. labor market: employment and wage differentials by skill. Labor Economics, 49, 106-127.

Brown, M.S. (2000). Religion and Economic Activity in the South Asian Population. Ethnic and Racial Studies, 23 (6), 1035-1061.

Busso, M., Muñoz, J. S. and Montaño, S. (2020). Unbundling Returns to Degrees and Skills. IDB Working Paper No. IDBWP-1089.

Brynin, M. and Guveli, A. (2012). Understanding the ethnic pay gap in Britain. Work Employment and Society, 26 (4), 574-587.

Budría, S. and Pereira, P.T. (2005). Educational qualifications and wage inequality: Evidence for Europe. IZA Discussion Paper Series No: 1763.

Card, D. (1999). The causal effect of education on earnings. Handbook of Labor Economics (Chapter 30). Netherland: Elsevier, 1801-1863.

Casero, P. A., and Seshan, G. (2006). Public-Private Sector Wage Differentials and Returns to Education in Djibouti. Washington: World Bank, Policy Research Working Papers No:3923.

Celik, O. and Selim, S. (2014). Turkiye'de Kamu ve Ozel Sektor Ucret Farkliliklarinin Kantil Regresyon Yaklasimi ile Analizi. Yonetim ve Ekonomi: Celal Bayar Universitesi Iktisadi ve Idari Bilimler Fakultesi Dergisi, 21(1), 205-232.

Celik, O. and Selim, S. (2016). Gender-Based Regional Wage Differentials in Turkish Labour Market: Quantile Regression Approach. Journal of Social Sciences, IX (2), 168-193.

Christofides, L. N., Polycarpou, A. and Vrachimis, K. (2013). Gender wage gaps, 'sticky floors' and 'glass ceilings' in Europe. Labor Economics, 21, 86-102.

Cörvers, F. (1997). The impact of human capital on labour productivity in manufacturing sectors of the European Union. Applied Economics, 29 (8), 975-987

Cudeville, E. and Gurbuzer, L. Y. (2007). Gender wage differentials in the Turkish labor market. Documents de travail du Centre d'Economie de la Sorbonne 2007.67 - ISSN: 1955611X. 2007, Paris.

Dayioglu, M. and Kasnakoglu, Z. (1997). Kentsel kesimde kadin ve erkeklerin isgucune katilimlari ve kazanc farkliliklari. METU Studies in Development, 24, 329-361. 
De la Rica, S., Dolado, J. J. and Llorens, V. (2008). Ceiling or floors: gender wage gaps by education in Spain. Journal of Population Economics, 21 (3), 751-776.

Denison, E. F. (1962). The Sources of Economic Growth in the United States and the Alternatives Before Us. New York: Committee for Economic Development.

Dewen, W, Fang, C. and Guoqing, Z. (2010). Factors Influencing Migrant Workers' Employment and Earnings-The Role of Education and Training. Social Sciences in China, 31 (3), 123-145.

Dustmann, C. and van Soest, A. (1997). Wage structures in the private and public sectors in West Germany. Fiscal Studies, 18 (3), 225-247.

Ersaslan, V. (2012). Turkiye Isgucu Piyasasinda Ucret Seviyesinde Cinsiyet Ayrimciligi: Blinder-Oaxaca Ayristirma Yontemi. Istanbul Universitesi Iktisat Fakültesi Mecmuasi, 62 (1), 231-248.

Eyiusta, C. and Ilhan, B. (2015). Lisansustu Egitimin Calışanların Is Performanslari Uzerindeki Etkisi: Beseri Sermaye Teorisi Yaklasimi. Anadolu Universitesi Sosyal Bilimler Dergisi, 15 (3), 113-126.

Fitzenberger, B. and Kunze, A. (2005). Vocational Training and Gender: Wages and Occupational Mobility Among Young Workers. Oxford Review of Economic Policy, 21 (3), 392-415.

Fortin, N. M. (2008). The Gender Wage Gap among Young Adults in the United States: The Importance of Money versus People. The Journal of Human Resources, 43 (4), 884-918

García, J., Hernández, P. J., and López-Nicolás, A. (2001). How Wide is the Gap? An Investigation of Gender Wage Differences Using Quantile Regression. Empirical Economics, 26 (1), 149-167.

Garcia-Suaza, A. F., Guataqui, J. C., Guerra, J. A. and Maldonado, D. (2009). Beyond the Mincer equation: the internal rate of return to higher education in Colombia. Education Economics, 22 (3), 328-344.

Gardeazabal, J. and Ugidos, A. (2005). Gender wage differentials at quantiles. Journal of Population Economics. 18 (1), 165-179.

Guner, F. D. (2009). Gender Based Wage Differentials in the Turkish Labor Market. Istanbul Technical University, Master Thesis, Istanbul.

Gurler Kiren, O., and Ucdogruk, S. (2007). Turkiye'de Cinsiyete Göre Gelir Farkliliginin Ayristirma Yontemiyle Uygulanmasi. Journal of Yasar University, 2 (6), 571-589.

Heath, A. and Martin, J. (2013). Can religious affiliation explain 'ethnic' inequalities in the labor market? Ethnic and Racial Studies, 36 (6), 1005-1027.

Heinze, A. (2010). Beyond the Mean Gender Wage Gap: Decomposition of Differences in Wage Distributions Using Quantile Regression. Mannheim: Centre for European Economic Research (ZEW) Discussion Paper No. 10-043.
Huy, T. H. (2020). Analysis of Earnings Determinants and Earnings Differentials among Urban Laborers in Some Southern Cities of Viet Nam. Asian Journal of Economics and Finance, 2(4), 289-307.

Hyder, A. and Reilly. B. (2005). The public and private sector pay gap in Pakistan: A quantile regression analysis. The Pakistan Development Review, 44 (3), 271-306.

ILO. (2018). Global Wage Report 2018 / 19: What Lies behind Gender Pay Gaps. Geneva. ISBN 978-92-2-031346-6

Ilkkaracan, I. and Selim, R. (2007). The gender wage gap in the Turkish labor market. Labor, 21 (3), 563-593.

Ismail, R. (2011). Gender Wage Differentials in the Malaysian Services Sector. African Journal of Business Management, 5 (19), 7781-7789.

Ismail, R. and Jajri, I. (2012). Gender Wage Differentials and Discrimination in Malaysian Labour Market. World Applied Sciences Journal, 19 (5), 719-728.

Jacobsen, J. P., and Skillman, G. L. (2004). Labor Markets and Employment Relationships: A Comprehensive Approach (First Edition). United Kingdom: Blackwell Publishing 374-429.

Jones, C. I. (1996). Human Capital, Ideas, and Economic Growth. Prepared for The VIII Villa Mondragone International Economic Seminaron Finance, Research, Education, and Growth in Rome, June 25-27, 1-28.

Jorgenson, D. W., and Griliches, Z. (1972). Issues in growth accounting: a reply to Edward F. Denis. Survey of Current Business, 52 (2), 65-94.

Kara, O. (2006). Occupational Gender Wage Discrimination in Turkey. Journal of Economic Studies. 33 (2), 130-143.

Koenker, R., and Bassett, G. (1978). Regression Quantiles. Econometrica, 46 (1), 33-50.

Koenker, R. and Hallock, K. F. (2001). Quantile Regression. Journal of Economic Perspectives, 15 (4), 143-156.

Lang, K. and Lehmann, J.-Y.K. (2012). Racial discrimination in the labor market: Theory and empirics. Journal of Economic Literature, 50 (4), 959-1006.

Lemieux, T. (2006). Post-secondary education and increasing wage inequality. Cambridge: National Bureau of Economic Research, Working Paper No:12077.

Lindley, J. (2002). Race or religion? The impact of religion on the employment and earnings of Britain's ethnic communities. Journal of Ethnic and Migration Studies, 28 (3), 427-442.

Lucas, R. E. (1988). On the Mechanics of the Economic Development. Journal of Monetary Economics, 22 (1), 3-42.

Lucifora, C. and Meurs, D. (2006). The public sector pay gap in France, Great Britain and Italy. Review of Income and Wealth, 52 (1), 43-59.

Maazouz, M. (2013). Return To Investment In Human Capital and Policy of Labour Market: Empirical Analysis Of Developing Countries. Procedia Economics and Finance, 5, 524-531 
Machado, J. A. F. and Mata, J. (2005). Counterfactual decomposition of changes in wage distributions using quantile regression. Journal of Applied Econometrics. 20 (4), 445-465.

Mankiw, N. G., Romer D., and Weil, D. N. (1992). A Contribution to the Empirics of Economic Growth. The Quarterly Journal of Economics, 107 (2), 407-437.

Martinez-Sanchis, E., Mora, J., and Kandemir, I. (2012). Counterfactual distributions of wages via quantile regression with endogeneity. Computational Statistics and Data Analysis, 56 (11), 3212-3229.

McConnell, C. R., Brue, S. L. and Macpherson, D. (2013). Contemporary Labor Economics. (10th Edition). United States: McGraw Hill, 430-437.

Melly, B. (2005). Decomposition of Differences in Distribution Using Quantile Regression. Labour Economics, 12 (4), 577-590.

Mercan, M. A. and Karakas, M. (2015). Industry-level women-male wage gap in turkey. Turk Dunyası Sosyal Bilimler Dergisi, 73, 157-170.

Meurs, D. and Ponthieux, S. (2005). The Gender Wage Gap in Europe: Women, Men and the Public Sector. Working Papers ERMES 0504, ERMES, University Paris 2.

Mincer, J. A. (1958). Investment in human capital and personal income distribution. The Journal of Political Economy, 66 (4), 281-302.

Mincer, J. A. (1974). Schooling, Experience and Earning. United States of America: National Bureau of Economic Research, 71-94.

Modood, T. (2003). Ethnic differences in educational performance. In Mason, D. (Ed.). Bristol Policy Press, 53-67.

Neal, D.A. and Johnson, W.R. (1996). The role of premarket factors in black-white wage differentials. The Journal of Political Economy, 104 (5), 869-895.

Nour, S. (2011). Estimating the Rate of Return to Education in Sudan. UNU-MERIT, Maastricht Economic and Social Research and Training Centre on Innovation and Technology. UNU-MERIT Working Papers No. 033.

Oaxaca, R. (1973). Male-women wage differentials in urban labor markets. International Economic Review, 14 (3), 693709.
Oaxaca, R. L., and Ransom, M. R. (1994). On Discrimination and the Decomposition of Wage Differentials. Journal of Econometrics, 61(1), 5-21.

Ozcan, Y. Z., Ucdogruk, S., and Ozcan, K. M. (2003). Wage Differences by Gender, Wage and Self Employment in Urban Turkey. Journal of Economic Cooperation and Development, 24(1), 1-24.

Ozcatal, E. (2011). Ataerkillik, Toplumsal Cinsiyet ve Kadinin Calisma Yasamına Katilimi. Cankırı Karatekin Universitesi Iktisadi ve Idari Bilimler Fakultesi Dergisi, 1 (1), 21-39.

Psacharopoulos, George, (1994). Returns to Investment in Education: A Global Update. World Development, 22(9), 1325-1343.

Schultz, T. W. (1961). Investment in human capital. The American Economic Review, 51 (1), 1-17.

Silber, J. and Weber, M. (1999). Labour Market Discrimination: Are There Significant Differences Between the various Decomposition Procedures? Applied Economics, 31(3), 359-365.

Tansel, A. (2003). Wage earners, self-employed and gender in the informal sector in Turkey. Cairo: Economic Research Forum Working Papers 0102.

Tansel, A. (2005). Public-private employment choice, wage differentials and gender in Turkey. Economic Development and Cultural Change, 53 (2), 453-477.

Tansel, A. and Bircan Bodur, F. (2012). Wage inequality and returns to education in Turkey: A quantile regression analysis. Review of Development Economics, 16 (1), 107-121.

Thrane, C. (2008). Earnings Differentiation in the Tourism Industry: Gender, Human Capital and Socio-Demographic Effects. Tourism Management, 29 (3), 514-524.

TurkStat. (2017). Household Budget Survey Micro Data Set, Ankara.

UN (United Nations). (2017). The Sustainable Development Goals Report 2017. New York.

Zhou, X.Z., Zhao, Y.B., Chou, L.C.., and Leivang, B.H. (2019). Changes in Gender Wage Differentials in China: A Regression and Decomposition Based on the Data of CHIPS1995-2013. Ekonomska Istrazivanja, 32(1), 31683188. 